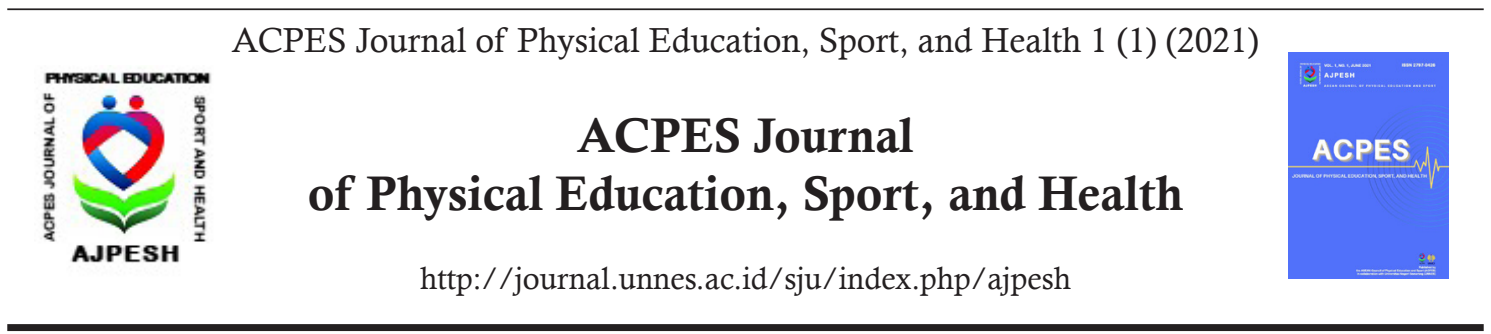

\title{
The Effect of Circuit Training and Beetroot Training on the In- creased Endurance of Karate Athletes
}

\author{
Liliana Puspa Sari ${ }^{\circledR}$, Della Sundari ${ }^{1}$, Dicky Hendrawan ${ }^{1}$, Alan Alfiansyah Putra Karo \\ Karo $^{1}$, Khairul Usman ${ }^{2}$
}

${ }^{1}$ Sekolah Tinggi Olahraga dan Kesehatan Bina Guna, Indonesia

${ }^{2}$ Universitas Negeri Medan, Indonesia

DOI: https://doi.org/10.15294/ajpesh.v1i1.46299

\section{Article Info}

Article History

Submitted 5 January 2021

Revised 22 April 2021

Accepted 19 June 2021

Keywords

Endurance; Circuit

Training; Bit Fruit

\begin{abstract}
The purpose of this study was to determine the effect of Circuit Training training and beetroot giving to the improvement of endurance abilities in karate athletes. This research method using experimental methods. Population and sample were 10 athletes of Karate Dojo at SMA PAB 4 Sampali who were obtained by total sampling technique, then divided into two groups using matching pairing techniques, namely the Circuit Training training group and giving beets and without giving beets (control group). The research instrument for data collection using tests and measurements, namely the Bleeb test endurance test. The first hypothesis $0.120>$ 0.05 , Ha is rejected, meaning that the first hypothesis Ho is accepted, there is no significant effect of Circuit Training training and Beetroot Training on the increase in athlete's endurance. The second hypothesis $0.183>0.05$, Ha is rejected, meaning that the conclusion of the second hypothesis Ho is accepted there is no significant effect of Circuit Training without giving beet fruit (control group) on the increase in athlete's endurance. The third hypothesis shows that the Sig. 0.757>0.05, then $\mathrm{Ha}$ is rejected, that is, there is no significant difference between the average value of the post-training circuit training and the giving of beets between the experimental group without giving beets (control group).
\end{abstract}

\section{INTRODUCTION}

Karate is one of the leading sports in Indonesia. One of the evidences is the number of karate tournaments held in Indonesia starting from the local level such as the regional, national, national competitions and even international competitions such as the open-open world championships held in Indonesia. The development of karate organizations and dojos, as well as the improvement of the quality of the Karate trainers' resources through courses and training are also other indicators of the high interest of the Indonesian people towards karate. Some schools also use karate as an extracurricular activity in schools such as Markus Medan Elementary School, State Middle School 6, and PAB 4 Sampali High School.

Circuit training is an exercise program that requires participants to do a training activity in a short time, using moderate level weights, high repetitions, and short 
rest periods and then continue with other circuit training programs (Dwijayanti \& Supriyoko, 2020). This exercise program will be able to provide a new challenge for the muscles and cardiovascular system. This training program is often carried out by athletes to increase endurance and strength (Ramadan \& Sidik, 2019). Regarding its implementation, Satria (2018) stated that circuit training is a training program consisting of several stations and at each station an athlete performs a predetermined type of exercise. And for the same understanding, Bompa stated that the training circuit is one of the names of exercises with stations that are carried out in circles or sequentially until they return to their original state which can consist of 6-9 station short circuits, 9-12 intermediate circuits, 12-15 long circuits.

A balanced intake of nutrients affects the appearance of an athlete when competing (Surbakti, 2010). Consumption of energy and nutrients that are less or more than the total requirement will generally have an adverse effect on the physiological functions of the body. On the one hand, a balanced nutritional intake has been known to affect the appearance of an athlete both during competition and during training (Rismayanthi, 2015).

The regulation and monitoring of balanced nutritional intake, including the selection of the right nutrition for athletes, is still rare, even not implemented optimally, so there is often a misperception about proper nutrition to meet the needs of athletes . Z, 2017). For example, electrolyte drinks that play a role in rehydrating fluids and electrolytes tend to be used as a source of energy for athletes during exercise. Supplements on the market, for example, such as EsterC Non-Acidic Vitamin $\mathrm{C}$, Vege Blend contain 21 vegetable extracts, Enervon C Multivitamins and many more. These supplements are usually made from natural and synthetic ingredients. Although the body tends to find it difficult to absorb supplements made from synthetic ingredients, the prices of these supplements vary, and some are expensive. Even though nature provides various kinds of fruit that can be used as supplements or immune-boosting juices, for example, beets.

Beets are one type of food that is useful and rich in nutrients. The pigment found in red beets is betalain (Mutiara, et al., 2016). Beets contain several active compounds such as carotenoids, glycine betaine, saponins, betasianin, betanine, polyphenols and falvonoids (Singh and Hathan, 2013). Beets are rich in carbohydrates that are easy to use as energy and iron, which helps the blood carry oxygen to the brain. Based on the problems found, the authors are interested in conducting a study with the title "the effect of Circuit Training training and the giving of beets to the increasing endurance of karate athletes in Dojo SMA PAB 4 Sampali.

\section{METHOD}

This research method is quasi-experimental research. Experimental research is research that is intended to determine whether there is an effect or not on subjects subject to treatment by Mardhika (2020). The research design used was "two groups pre-test-post-test design", namely a research design that contained a pre-test before being given treatment and a post-test after being treated, thus it can be known to be more accurate, because it can compare with those held before. given treatment (Primayanti \& Isyani, 2019). Population is the subject of research. The population in this study were 10 athletes of the karate dojo at SMA PAB 4 Sampali. The sample is a 
part or representative of the population under study (Lubis \& Wulandari, 2018). The criteria in determining this sample include: (1) attendance of $75 \%$ (2) karate athletes assisted by the dojo of SMA PAB 4 Sampali, (3) aged 16-19 years, (4) male and female, (5) old minimum training for one year, (6) athletes have yellow belt and above, (7) have participated in a competition at least once. Based on these criteria, there are 10 athletes.

The sample was divided into two groups, Group A was given the Circuit Training training method and giving beets, then group B was given only Circuit Training training. The results of grouping based on ordinal pairing are as follows:

Table 1. Ordinal Pairing

\begin{tabular}{cc}
\hline Group A & Group B \\
\hline 1 & 2 \\
4 & 3 \\
5 & 6 \\
8 & 7 \\
9 & 10 \\
\hline
\end{tabular}

Data collection in this study was the bleep test (multi-stage running test). This test is done at the beginning of the pretest before being treated and at the end of the post test after being treated, and from this data it can be seen how the level of endurance (endurance) athletes.

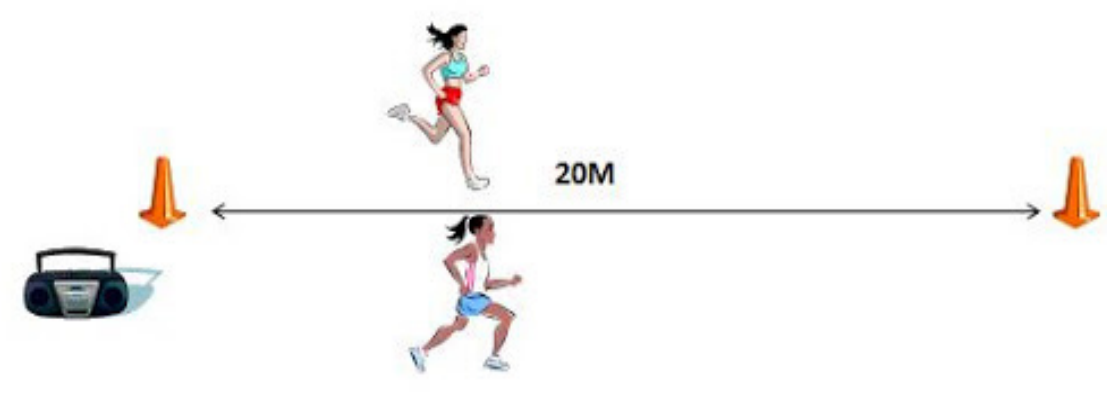

Figure 1. The bleep test trajectory

Before testing the hypothesis, it is necessary to do a prerequisite test. Testing the measurement result data related to the research results aims to help the analysis to be better (Soniawan \& Irawan, 2018). For this reason, this study will test the normality and homogeneity of the data. Hypothesis testing uses the t-test using the help of the SPSS 22 program (Hulfian, 2019), namely by comparing the mean between the pretest and post-test. If the $\mathrm{t}$ value is smaller than the $\mathrm{t}$ table, then $\mathrm{Ha}$ is rejected, if the $\mathrm{t}$ count is greater than the $\mathrm{t}$ table then $\mathrm{Ha}$ is accepted (Nur, 2019).

\section{RESULT AND DISCUSSION}

The results of tests and measurements carried out in the field are the findings of a study that was carried out for 6 weeks. Done to reveal the truth of the hypot- 
hesis that has been proposed. The results of tests and measurements that have been processed through the SPSS version 22 statistical formula show the data description as follows:

Table 2. Pre-Test and Post-Test Results of the Circuit Training Group and Giving Beets with Beet-Free Exercises on Increasing Endurance Results

\begin{tabular}{lccccc}
\hline & $\mathrm{N}$ & Minimum & Maximum & Mean & Std. Deviation \\
\hline Pre-Test Experiment & 5 & 27 & 38 & 31.80 & 4.494 \\
Post-Test Experiment & 5 & 31 & 43 & 36.80 & 4.604 \\
Pre-Test Control & 5 & 26 & 37 & 31.40 & 4.219 \\
Post-Test Control & 5 & 27 & 41 & 35.80 & 5.263 \\
Valid N (listwise) & 5 & & & & \\
\hline
\end{tabular}

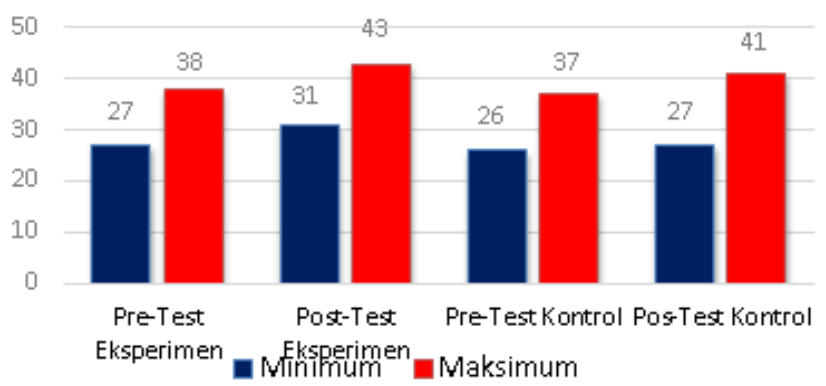

Figure 3. Comparison of Minimum and Maximum Pre-Test and Post-Test Results

From the pre-test results in the circuit training exercise group without the addition of beet nutrition (control group) to the increase in VO2Max results with $\mathrm{N}=5$, it was obtained a range between 26.37 - 37 with an average of 31.40 and a standard deviation of 4.219 . From the results of the post-test with $\mathrm{N}=8$, it was obtained between 27 - 41 with an average of 35.80 and a standard deviation of 5.263. From the average pre-test and post-test, the difference value is 4.40 with a standard deviation of difference of 1.04. From the final data processing between the Circuit Training training group and the giving of beets to increase endurance, the combined standard deviation value is 4.604 .

Table 3. Data Normality Test

\begin{tabular}{llcccccc}
\hline \multirow{2}{*}{ Kelas } & \multicolumn{3}{c}{ Kolmogorov-Smirnov ${ }^{\mathrm{a}}$} & \multicolumn{3}{c}{ Shapiro-Wilk } \\
\cline { 3 - 7 } & & Statistic & df & Sig. & Statistic & df & Sig. \\
\hline Athlete & Pre-test Experiment Class BBit & .201 & 5 & $.200^{*}$ & .950 & 5 & .734 \\
Training & Post-Test Experiment Class BBit & .128 & 5 & $.200^{*}$ & .994 & 5 & .992 \\
Results & Pre-test Class Group control & .230 & 5 & $.200^{*}$ & .962 & 5 & .822 \\
& Post-Test Class Group control & .315 & 5 & .117 & .865 & 5 & .245 \\
\hline
\end{tabular}

Testing the normality of data using the df normality test with the KolmogorovSmirnova and Shapiro-Wilk tests, from the pre-test column for Circuit Training train- 
ing by giving beets to increase endurance obtained Kolmogorov-Smirnova $=0.200>$ 0.05 and Shapiro- Wilk $=0.737>0.05$ with $\mathrm{N}=5$ and the real level $\alpha=0.05$. Due to the calculation of both ways that the calculated value through Kolmogorov-Smirnova $=0.200>0.05$ and Shapiro-Wilk $=0.737>0.05$, it can be concluded that the sample comes from a normal population. From the post-test list column exercise with additional beetroot nutrition to increase VO2Max results obtained Kolmogorov-Smirnova $=0.200>0.05$ and Shapiro-Wilk $=0.992>0.05$ with $\mathrm{N}=5$ and the real level $\alpha$ $=0.05$. Due to the calculation of the two ways that the calculated value through Kolmogorov-Smirnova $=0.200>0.05$ and Shapiro-Wilk $=0.992>0.05$, it can be concluded that the sample comes from a normal population.

From the pre-test list column of Circuit Training training without additional nutrition of beetroot (control group) for increased endurance, it was found that Kolmogorov-Smirnova $=0.200>0.05$ and Shapiro-Wilk $=0.822>0.05$ with $\mathrm{N}=5$ and the real level $\alpha=0,05$. Due to the calculation of the two ways that the calculated value through Kolmogorov-Smirnova $=0.200>0.05$ and Shapiro-Wilk $=0.822>0.05$, it can be concluded that the sample comes from a normal population.

From the post-test list column Circuit Training training without any additional nutrition of beets (control group) for increased endurance, it was found that Kolmogorov-Smirnova $=0.117>0.05$ and Shapiro-Wilk $=0.245>0.05$ with $\mathrm{N}=5$ and the real level $\alpha=0,05$. Due to the calculation of the two ways that the calculated value through Kolmogorov-Smirnova $=0.117>0.05$ and Shapiro-Wilk $=0.245>0.05$, it can be concluded that the sample comes from a normal population.

Table 4. Data Homogeneity Test

\begin{tabular}{llllll}
\hline & & Levene Statistic & df1 & df2 & Sig. \\
\hline Athlete & Based on Mean & .002 & 1 & 8 & .968 \\
Train- & Based on Median & .009 & 1 & 8 & .929 \\
ing & Based on Median and with adjusted & .009 & 1 & 6.794 & .929 \\
Results & df & & & & \\
& Based on trimmed mean & .001 & 1 & 8 & .983 \\
\hline
\end{tabular}

The pre-test data homogeneity test on the results of Circuit Training training by giving beets to increase endurance obtained the output with a significance value (Sig) Based on Mean 0.968>0.05, so it can be concluded that the posttest data variant is experimental class. Exercise with additional nutrition of beets to increase VO2Max is equally homogeneous.

Based on the results of the normality and homogeneity test, it was found that the research data on the score of Circuit Training training by adding beetroot nutrition were normally distributed and had homogeneous variances, so the requirements for data analysis were fulfilled. Furthermore, hypothesis testing is carried out by means of an independent t-test analysis which is intended to test the hypothesis of the main effect.

Based on the results of the first hypothesis test, it can be concluded that the mean value of the pre-test and post-test results is an increase in the results of Circuit Training training and the giving of beets with an average pre-test of 31.80 and an increase of 36 post-test results. , 80 with a difference of 5.00 but a significant increase 
in view of Table 4.5. The independent sample test output is in the Equal variances assumed sig. (2-tailed) column $0.120>0.05$, Ha is rejected, meaning that Ho's first hypothesis is accepted, there is no significant effect of Circuit Training and Giving Bit Fruit training on the increased endurance of high school Karate Dojo athletes. PAB 4 Sampali in 2020.

Table 5. Group Statistics

\begin{tabular}{llrlll}
\hline & Group & \multirow{2}{*}{ N } & Mean & $\begin{array}{l}\text { Std. } \\
\text { Deviation }\end{array}$ & $\begin{array}{l}\text { Std. } \\
\text { Error Mean }\end{array}$ \\
\hline $\begin{array}{llllll}\text { Result Training } \\
\text { CT BB }\end{array}$ & Pre-Test CT BB Training & 5 & 31.80 & 4.494 & 2.010 \\
& Post-Test CTBB Training & 5 & 36.80 & 4.604 & 2.059 \\
\hline
\end{tabular}

Based on the results of the second hypothesis test, it can be concluded that the mean value of the pre-test and post-test results is an increase in the results of Circuit Training training without giving beets (Control Group) with an average pre-test of 31.40 and increasing by an average post-test 35.80 with a difference of 4.40 , but a significant increase can be seen in Table 4.7. The independent sample test output is in the Equal variances assumed sig. (2-tailed) column 0.183>0.05, Ha is rejected, meaning that the conclusion of Ho's second hypothesis is accepted that there is no significant effect of Circuit Training without Giving Bit Fruit (control group) on increased endurance Karate Dojo athlete SMA PAB 4 Sampali in 2020.

Table 6. Independent Samples Test

\begin{tabular}{|c|c|c|c|c|c|c|c|c|c|c|}
\hline \multirow[b]{3}{*}{$\mathrm{F}$} & & \multicolumn{2}{|c|}{$\begin{array}{l}\text { Levene's } \\
\text { Test for } \\
\text { Equality of } \\
\text { Variances }\end{array}$} & \multicolumn{6}{|c|}{ t-test for Equality of Means } & \\
\hline & & \multirow[t]{2}{*}{ Sig. } & \multirow[t]{2}{*}{$\mathrm{t}$} & \multirow[t]{2}{*}{$\mathrm{df}$} & \multirow[t]{2}{*}{$\begin{array}{l}\text { Sig. } \\
\text { (2-tailed) }\end{array}$} & \multirow[t]{2}{*}{$\begin{array}{l}\text { Mean } \\
\text { Differ- } \\
\text { ence }\end{array}$} & \multirow{2}{*}{$\begin{array}{l}\text { Std. } \\
\text { Error } \\
\text { Differ- } \\
\text { ence }\end{array}$} & \multicolumn{2}{|c|}{$\begin{array}{l}95 \% \text { Confidence } \\
\text { Interval of the } \\
\text { Difference }\end{array}$} & \\
\hline & & & & & & & & Lower & Upper & \\
\hline \multirow[t]{2}{*}{$\begin{array}{l}\text { Result } \\
\text { Training } \\
\text { CT BB }\end{array}$} & $\begin{array}{l}\text { Equal } \\
\text { variances } \\
\text { assumed }\end{array}$ & .000 & 1.000 & -1.738 & 8 & .120 & -5.000 & 2.877 & -11.636 & 1.636 \\
\hline & $\begin{array}{l}\text { Equal vari- } \\
\text { ances not } \\
\text { assumed }\end{array}$ & & & -1.738 & 7.995 & .121 & -5.000 & 2.877 & -11.636 & 1.636 \\
\hline
\end{tabular}

Table 7. Group Statistics

\begin{tabular}{|c|c|c|c|c|c|}
\hline & Group & $\mathrm{N}$ & Mean & $\begin{array}{l}\text { Std. De- } \\
\text { viation }\end{array}$ & $\begin{array}{l}\text { Std. Er- } \\
\text { ror Mean }\end{array}$ \\
\hline \multirow{2}{*}{$\begin{array}{l}\text { Result Train- } \\
\text { ing CT control }\end{array}$} & Pre-Test CT BB Training & 5 & 31.40 & 4.219 & 1.887 \\
\hline & Post-Test CTBB Training & 5 & 35.80 & 5.263 & 2.354 \\
\hline
\end{tabular}


Table 8. Independent Samples Test

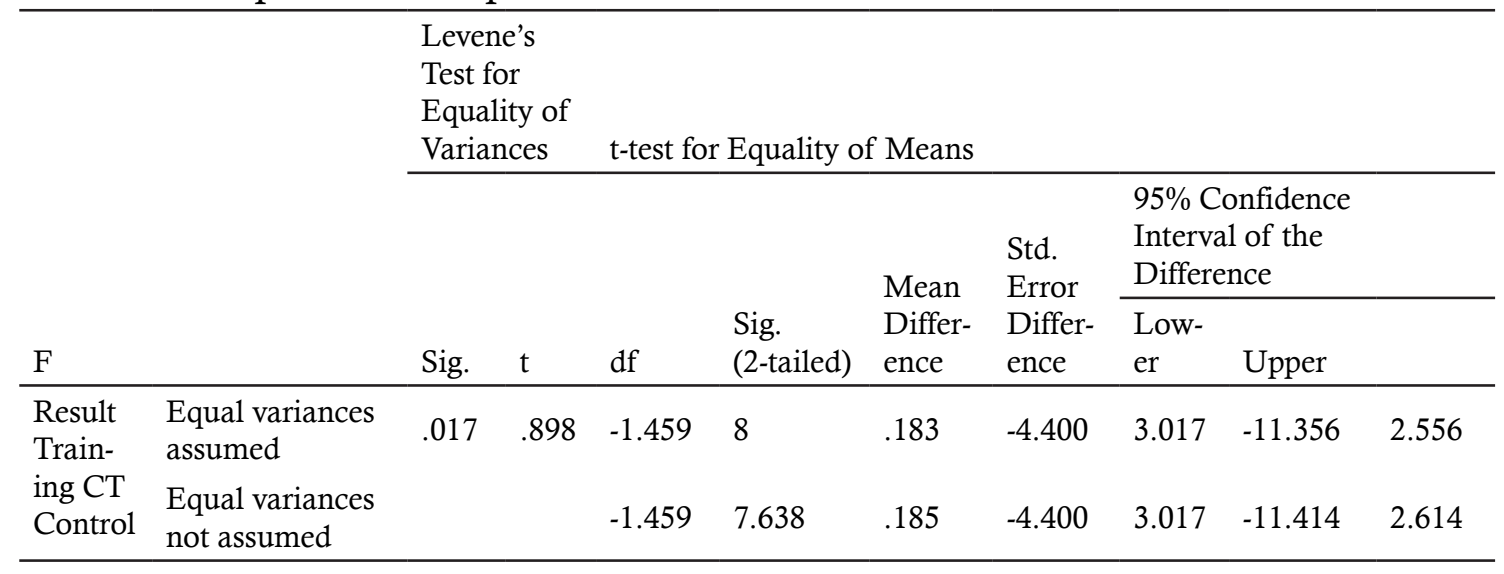

Based on the results of the third hypothesis test. Based on the table below, the Sig value in column $\mathrm{F}$ is greater than $0.05(0.968>0.05)$, it can be assumed that the $\mathrm{F}$ value has the same homogeneous variance. The results of the $\mathrm{T}$ test using the Independent Samples T Test show that the Sig. 0.757> 0.05, then Ha is rejected, that is, there is no significant difference between the average value of the post-training circuit training and the giving of beets between the experimental group without giving beets (control group). From the results of the Circuit Training training hypothesis test shows that $\mathrm{Ha}$ is rejected, which means that there is no significant difference in the Circuit Training training and beetroot giving to athletes in the experimental group with the group without giving beets (control group).

Table 9. Group Statistics

\begin{tabular}{|c|c|c|c|c|c|}
\hline & Kelas & $\mathrm{N}$ & Mean & $\begin{array}{l}\text { Std. De- } \\
\text { viation }\end{array}$ & $\begin{array}{l}\text { Std. Er- } \\
\text { ror Mean }\end{array}$ \\
\hline Athlete Training & Post-Test Experiment BBit & 5 & 36.80 & 4.604 & 2.059 \\
\hline Results & Post-Test Control & 5 & 35.80 & 5.263 & 2.354 \\
\hline
\end{tabular}

Table 10. Independent Samples Test

\begin{tabular}{|c|c|c|c|c|c|c|c|c|c|c|}
\hline \multirow[b]{3}{*}{$F$} & & \multicolumn{2}{|c|}{$\begin{array}{l}\text { Levene's Test } \\
\text { for Equality } \\
\text { of Variances }\end{array}$} & \multicolumn{7}{|c|}{ t-test for Equality of Means } \\
\hline & & \multirow[t]{2}{*}{ Sig. } & \multirow[t]{2}{*}{$\mathrm{t}$} & \multirow[t]{2}{*}{$\mathrm{df}$} & \multirow[t]{2}{*}{$\begin{array}{l}\text { Sig. } \\
\text { (2-tailed) }\end{array}$} & \multirow{2}{*}{$\begin{array}{l}\text { Mean } \\
\text { Differ- } \\
\text { ence }\end{array}$} & \multirow{2}{*}{$\begin{array}{l}\text { Std. } \\
\text { Error } \\
\text { Differ- } \\
\text { ence }\end{array}$} & \multicolumn{3}{|c|}{$\begin{array}{l}\text { 95\% Confidence } \\
\text { Interval of the } \\
\text { Difference }\end{array}$} \\
\hline & & & & & & & & Lower & Upper & \\
\hline \multirow{2}{*}{$\begin{array}{l}\text { Athlete } \\
\text { Train- } \\
\text { ing } \\
\text { Results }\end{array}$} & $\begin{array}{l}\text { Equal } \\
\text { variances } \\
\text { assumed }\end{array}$ & .002 & .968 & .320 & 8 & .757 & 1.000 & 3.127 & -6.212 & 8.212 \\
\hline & $\begin{array}{l}\text { Equal } \\
\text { variances } \\
\text { not as- } \\
\text { sumed }\end{array}$ & & & .320 & 7.861 & .757 & 1.000 & 3.127 & -6.234 & 8.234 \\
\hline
\end{tabular}


If we look at the pre-test results of the Karate Dojo athletes at SMA PAB 4 Sampali, who have been training for a long time and have obtained a belt above yellow, their physical condition is generally considered to be inadequate with an average value of 31.48 , it is assumed that all samples are not serious, or they are in physical condition. the athlete is low / lacking. From the pretest data, the program was designed for 16 meetings with a frequency of 3 times a week.

Every kata or kumite karate match number must be supported by excellent physical condition (Asnaldi, A, 2015). Physical conditions are seen as fundamental for athletes, because without the support of excellent physical conditions, achieving maximum performance will be difficult to materialize (Pujianto, 2015). The components of the physical conditions needed by a karateka when competing include strength (strength), speed (speed), agility, endurance, flexibility, coordination (coordination) accuracy and reaction ( reaction), and the dominant movements of karate such as hitting, kicking, and parrying are dominated by arm movements when hitting and parrying as well as the legs when kicking, and other limbs act as supporters of the movement (Valiantianus \& Sepdanius, 2019).

From the results of the first and second hypothesis testing, the results of the data processing carried out can be seen that the two groups of exercises have no effect in increasing endurance, whether circuit training is not in accordance with the form of the test being carried out, namely the bleep test because the training program does a lot of on-site activities. (Rasidyanto et al., 2019) while the form of the test is in the form of running from one point to another with a very long time. Meanwhile, the form of the circuit in place and the program that was designed was not in accordance with the form of the test (Putri, et al, 2020).

From the results of the third hypothesis, it shows that circuit training and giving beets is not more influential than circuit training without giving beets to increase endurance in Karate Dojo athletes at SMA PAB 4 Sampali in 2020.

Both of these are due to the fact that the third hypothesis only sees which one has the greater influence from the two independent variables, namely circuit training and the giving of beets is superior to circuit training (Yola \& Rifki, 2020) without giving beets to Karate Dojo athletes at SMA PAB 4 Sampali in 2020. From the above explanation, it is concluded that circuit training and beetroot giving can be done because it is superior to circuit training exercises (Romadhoni et al., 2018) without giving beets to the Karate Dojo athletes of SMA PAB 4 Sampali in 2020.

\section{CONCLUSION}

From the results of the hypothesis testing, the following conclusions were drawn: Circuit Training and Beet Fruit Giving had an effect on increasing endurance in karate athletes at Dojo SMA PAB 4 Sampali in 2020. Circuit training without giving beets had an effect on increasing endurance abilities in athletes. Karate Dojo SMA PAB 4 Sampali in 2020. Circuit Training and Giving Beet Fruits have no greater effect on increasing endurance in Karate Dojo athletes at SMA PAB 4 Sampali in 2020, than Circuit Training without Giving Beets. 


\section{REFERENCES}

Asnaldi, A. 2015. Analisis Kondisi Fisik dalam Cabang Olahraga Karate. Sport Science: Jurnal Ilmu Keolahragaan dan Pendidikan Jasmani, 24(29): 13-28.

Dwijayanti, K., \& Supriyoko, A. 2020. Peningkatan pembelajaran gerak lokomotor menggunakan Model Aktivitas Sirkuit (MAS) melalui pos kemampuan anak siswa sekolah dasar. Journal of Physical Activity (JPA), 1(2): 91-101.

Hulfian, L. 2019. Kontribusi Kondisi Fisik Terhadap Keterampilan Bermain Cabang Olahraga Permainan. Gelora: Jurnal Pendidikan Olahraga dan Kesehatan, 6(1): 52-58.

Lubis, A. S., \& Wulandari, S. 2018. Pengaruh Employee Engagement dan Kepemimpinan terhadap Kinerja Pegawai pada Dinas Pariwisata, Budaya, Pemuda dan Olah Raga Kabupaten Serdang Bedagai. Jurnal Manajemen dan Keuangan, 7(1): 82-89.

Mardhika, R. (2020). Standing Jump Over Barrier Mempengaruhi Keterampilan Menendang Bola (Shooting) Cabang Olahraga Sepakbola. Jurnal Porkes, 2(2): 50-57.

Mutiara, S., Kusumo, E., \& Supartono, S. 2016. Identifikasi Betasianin Dan Uji Antioksidan Ekstrak Buah Bit Merah (Beta vulgaris L). Indonesian Journal of Chemical Science, 5(3): 217-220.

Nur, A. 2019. Pengaruh Latihan Lompat Rintangan terhadap Kemampuan Lompat Jauh Gaya Jongkok pada Siswa Putra SMP Negeri 1 Luwuk. Jurnal Pendidikan Olahraga, 9(1): $1-8$.

Primayanti, I., \& Isyani, I. 2019. Pengaruh Latihan Drill Dan Latihan Pola Pukulan Terhadap Kemampuan Smash Bulutangkis Pada PB. Liansa Junior Masbagik Lombok Timur Tahun 2019. Gelora: Jurnal Pendidikan Olahraga dan Kesehatan, 6(1): 25-31.

Pujianto, A. 2015. Profil Kondisi Fisik dan Keterampilan Teknik Dasar Atlet Tenis Meja Usia Dini di Kota Semarang. Journal of Physical Education Health and Sport, 2(1): 38-42.

Putri, A. E., Donie, D., Fardi, A., \& Yenes, R. (2020). Metode Circuit Training Dalam Peningkatan Daya Ledak Otot Tungkai Dan Daya Ledak Otot Lengan Bagi Atlet Bolabasket. Jurnal Patriot, 2(3): 680-691.

Ramadan, W., \& Sidik, D. Z. 2019. Pengaruh Metode Circuit Training Terhadap Daya Tahan Cardiovascular Cabang Olahraga Atletik Nomor Lari Jarak Jauh. Jurnal Kepelatihan Olahraga, 11(2): 101-105.

Rasidyanto, A., Supriatna, S., \& Sulistyorini, S. (2019). Metode Short Interval Training dan Long Interval Training untuk Meningkatkan Daya Tahan Umum pada Pemain U-14. Indonesia Performance Journal, 3(2): 71-79.

Rismayanthi, C. 2015. Sistem Energi Dan Kebutuhan Zat Gizi Yang Diperlukan Untuk Peningkatan Prestasi Atlet. Jorpres (Jurnal Olahraga Prestasi), 11(1): 109-121.

Romadhoni, D. L., Herawati, I., \& Pristianto, A. 2018. Pengaruh pemberian circuit training terhadap peningkatan vo2max pada pemain futsal di Maleo Futsal Magetan. Jurnal Kesehatan, 11(1): 43-48.

Satria, M. H. 2018. Pengaruh Latihan Circuit Training Terhadap Peningkatan Daya Tahan Aerobik Pemain Sepakbola Universitas Bina Darma. Jurnal Ilmiah Bina Edukasi, 11(01): 36-48.

Soniawan, V., \& Irawan, R. (2018). Metode Bermain Berpengaruh Terhadap Kemampuan Long Passing Sepakbola. Jurnal Performa Olahraga, 3(01): 42-42.

Surbakti, S. 2010. Asupan bahan makanan dan gizi bagi atlet renang. Jurnal Ilmu Keolahragaan, 8(02): 108-122.

Valiantianus, S., \& Sepdanius, E. 2019. Tinjauan Kemampuan Biomotorik Atlet Karate Dojo Kantor PU (Pekerjaan Umum) Kota Solok. JURNAL STAMINA, 2(2): 104-114.

Yola, F., \& Rifki, M. S. 2020. Pengaruh Latihan Sirkuit (Circuit Training) Terhadapvolume Oksigen Maksimal (VO2MAX) Pemain Sekolah Sepak Bola (SSB). JURNAL STAMI$N A, 3(6): 509-526$. 